\title{
Labor Market And New Dimensions Of Labor Relations: The Case Of Slovenia
}

Vlado Dimovski, University of Ljubljana, Slovenia

Jana Žnidaršič, (E-mail: jana.znidarsic@ef.uni-lj.si), University of Ljubljana, Slovenia

\begin{abstract}
The economic and social situation at the beginning of the 21st century is bringing new challenges also to labor - management relations all over the world. During the transition period, Slovenia was facing hard times in striving to build completely new market-oriented economic society. Because of the significance of labor-management relations to the new economy and political system, labor-related matters received much attention from the Slovenian economic development policy. Within socialist economic system unemployment actually did not exist, as the system was very protective. Labor relations were administratively regulated and all shortcomings broke out on the eve before the socialism collapsed. Transformation depression was accompanied with decline in economic activity in general and inflation, which both had negative impact on standard of living and employment. The registered unemployment rate was rising up to $14.4 \%$ in 1993. The most critical groups were those having no vocational education, older than 40 and those already being unemployed. The main reasons for employment stagnation and the persistent high registered unemployment rate could be found in economy's restructure initiated by a transition into market economy (bankruptcies) and the loss of Yugoslav markets (orientation on a more demanding European markets). Many enterprises faced inevitable failure; many workers were dismissed or got a status of being redundant. The problem was moderated with new retirement legislation, which enabled the possibility of early retirement, which consequently lowered the share of elder people employed and contributed to very modest share of part-time employed people. In Slovenia labor costs (taxes and social contributions paid by employees and employers) are the highest in the new EU member states with the exception of Cyprus. If Slovenia wants to boost employment and economic growth, it will have to implement the new labor-relations law and create a more flexible labor market. Considering that competitive advantage and economic growth are often achieved by reducing labor costs (and lower social security of employees) the regulation of labor relations needs very subtle actions. In the paper, we present the development of labor relations in Slovenia through three periods: planned economy, transition and post-transition period, high-lightening the recent trends, the key labor market development problems, as well as bringing forward the key orientations and policies - alleviating critical elements on this field.
\end{abstract}

\section{INTRODUCTION}

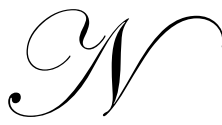

owadays, even unlimited amounts of goods and services cannot guarantee prosperity and material security to the citizens in any country or society. There are some issues involving problems of concern to both workers and their employers, such as: foreign competition, changing technology, productivity improvement, inflation, energy crisis, reorganization, rising unemployment, changing composition of the work force etc., which clearly indicate the uncertainty of our future. Accompanied with the issues encompassing ethics, social responsibility and cultural differences, they are bringing new challenges also to labor relations all over the world.

Today Slovenia is already facing, and is going to face in the future too, challenges of globalization, liberalization, adoption of "European" rules and the necessary transition from a transition - industrial society to a modern market economy. Technology development, necessary for Slovenia for not lagging behind the European Union (EU in text) average, is not possible without investment in human resources development. When building completely new market-oriented economic society in Slovenia, new dimensions of labor relations, intensifying the 
process of achieving the labor market flexibility, accompanied transition period. Because of the significance of labormanagement relations to the new economy and political system, labor-related matters will receive much our attention in this paper, when discussing the development of labor relations and labor market trends in Slovenia more in detail.

\section{LABOR RELATIONS IN SLOVENIA WITHIN SOCIALIST POLITICAL AND ECONOMIC REGULATION (PLANNED ECONOMY)}

The development of labor relations in Slovenia is specific. In the time period between the end of WW II and the late eighties (before Slovenia split of from Yugoslavia), labor relations were regulated within "The associated labor law", which reflected the political and economic regulation of that time. The socialist ideas of equality, social justice and solidarity with the weak, underprivileged and aged, and the promise of an economy of full employment without cyclical development, had a tremendous power of attraction after the war (Adam, 1996). Before 1974 and new constitution of former Yugoslavia, labor relations were still more or less "contract relations" or hired labor relationship between two parts, employee and employer. The employee was giving his working abilities at employer's disposal, whereas the employer was obligated to enable the worker the payment (wage). The possible exploitation of workers was not compatible with socialist economic and political system (Strohsack, 1981). In spite of the fact, that classic "employee - employer" relation has been changing evolutionary and working force has been getting more rights (e.g. less working-hours per week, the right to take some days off every year, social insurance, the right to unite etc.), the "exploitation moment" was still there. In accordance with socialist system, the "dual contract relation" between employer and employee was replaced with "mutual relation of workers in associated labor". New content (context) of labor relations presumed, that every worker was related to other workers (not employer), when pooling labor and resources, which were socially owned.

The labor relations switched from dual to multiple, where workers were sharing all decisions in socially owned company, as well as those, concerned salary proportions, mutual consumption and final income-disposition, even for example creating the fund for solving housing problem of employees (Šinkovec, 1983). The rights were connected with obligations and shared responsibility. Even those workers - employed by the private owners (in small private firms) had the same rights as workers, sharing their labor within socially owned enterprises of associated labor.

In the eighties unemployment actually (officially) did not exist, as the system was very protective. The social policy, understood broadly comprised the right to a job, quite an egalitarian distribution of income, stable and low prices for basic foods, services and shelter, and social security. In practice the right to a job meant job security: if a worker did not grossly violate the labor code, he did not have to fear losing his job, and if something went wrong he could easily find a new job. Workers enjoyed a great deal of certainty about the evolution of their real incomes, and they were also sure that, once they reached the retirement age, a pension would be available. They enjoyed an economic security - which was unparalleled in capitalist countries (Adam, 1996). It was stated in Constitution, that everyone - being able to work has the right to be employed and the socialist state was responsible to assure the "full employment". The unemployment was reduced to negligible frictional unemployment, as the consequence of those being unemployed for short periods when changing the job or those being unemployed in period - when involving in work - force (McConnell, Brue, 1995). It was also impossible to fire a worker. If economic difficulties appeared, reorganization or technologic improvements were involved, and consequently workers became redundant, the organization had to dispose the worker on the other suitable job within organization or, if this was not possible within, in other organization (Adam, 1996; Rozman, Novak, 1981; Šinkovec, 1983). A manager had to have a very good reason for dismissing a worker. Economically driven reasons, forcing enterprises to reduce their work force were allowed after 1989, even then the costs of dismissals were very high and the procedures complicated (Kajzer, 1996). On the other hand there was high "hidden unemployment": including those - being employed, but not efficiently (their work has not made a contribution to the final result).

The labor market was very rigid. It was working when employing, whereas it did not work when the excess of workers arose. The employment policy that was pursued contributed to full employment, but at the same time had a negative impact on economic efficiency and incentives. Full employment had its advantages but also many disadvantages due to the way it was achieved and maintained. There is no doubt, that unemployment is costly to 
society. It means a loss of output and taxes, increased state expenditures and causes social and psychological costs which cannot be quantified (Adam, 1996). On the other hand, full employment in socialist countries also had its costs. It became a source of underutilization of labor, lack of discipline in the workplace and an impediment to the restructuring of the economy. The enterprises were allowed neither to dismiss workers, nor to reduce wages in striving to reduce its costs to become more competitive on the regional and foreign markets. As workers were acting in different roles, including leadership and management - it was illusionary to expect to act against them-selves. The amazing effect could be observed: even when economic growth was stagnant in that period, the employment was increasing. Labor relations were completely administratively regulated and all shortcomings broke out on the eve before the socialism collapsed.

\section{ECONOMIC CHANGES IN TRANSITION PERIOD (1988 - 1998) - INFLUENCING LABOR MARKET AND LABOR RELATIONS}

The collapse of the socialist system was primarily the result of many internal economic and political factors. Of the economic factors four should be specially stressed (Adam, 1996): the increasing gap between the East and the West in the level of technology, the unfavorable development of the standard of living, the excessive socialization of the means of production, and the growing indebtedness. The unrealistic assumptions of socialist system, on which it was built, made it inefficient and consequentially economically exhausted. Even the social welfare policy (which was the main advantage of the system) worked in many respects against the efficiency of the economy; a good example for this is full employment, accompanied with the improper labor-management relations.

During the transition period, Slovenia was facing hard times in striving to build completely new marketoriented economic society. The transition from the planned to the market economy brought some crucial changes, for instance: independence (when splitting off from ex. Yugoslavia), the loss of traditional markets in the former state, necessity to transform completely to western - European markets (Table 1), privatization of former social property and major restructuring of giant enterprises to more medium and small companies (in text SMEs).

The Slovenian economy, which had changed from being a regional economy with an insufficient supply to become a national economy with an insufficient demand, succeeded in replacing the markets lost before. The foreign trade accounts made up more than a half of GDP and two-thirds of this was trade with the EU countries.

Table 1: Trade Between Slovenia And The Rest Of The World (In \% Of GDP)

\begin{tabular}{|l|c|c|c|c|c|c|}
\hline & \multicolumn{2}{|c|}{ Export } & \multicolumn{3}{c|}{ Import } \\
\hline & $\mathbf{1 9 9 0}$ & $\mathbf{1 9 9 2}$ & $\mathbf{1 9 9 7}$ & $\mathbf{1 9 9 0}$ & $\mathbf{1 9 9 2}$ & $\mathbf{1 9 9 7}$ \\
\hline Former Yugoslavia & 47,6 & 14,3 & 9,5 & 35,5 & 11,1 & 3,7 \\
\hline EC, EU12, EU15 & 18,8 & 34,6 & 36,6 & 19,3 & 28,2 & 39,4 \\
\hline - of which: (BR) Germany & 7,7 & 17,0 & 16,9 & 7,9 & 12,8 & 12,1 \\
\hline Italy & 5,9 & 8,3 & 8,6 & 3,9 & 7,7 & 9,7 \\
\hline other countries & 5,2 & 9,3 & 7,2 & 7,5 & 7,7 & 12,7 \\
\hline Rest of the world & 13,7 & 14,2 & 11,4 & 13,8 & 16,9 & 15,4 \\
\hline Total & 80,1 & 63,1 & 57,5 & 68,6 & 56,2 & 58,4 \\
\hline
\end{tabular}

Source: Institute for Macroeconomics Analysis and Development

The introduction of organizational and technological rationalization in companies in order to reduce costs and to improve competitiveness in Western markets, and inter-sectoral restructuring of economic activities marked by a gradual reduction in the proportions of agricultural and industrial activities in favor of services (Table 2), among other changes, also had effects on lower economic growth, lower standard of living etc., which all together clarified new issues, calling for immediate action. 
Table 2: Economic Growth, Employment And Labor Productivity In Slovenia (1988- 1998)

\begin{tabular}{|c|c|c|c|c|c|c|c|c|c|c|c|}
\hline & 1988 & 1989 & 1990 & 1991 & 1992 & 1993 & 1994 & 1995 & 1996 & 1997 & 1998 \\
\hline \multicolumn{12}{|l|}{ Annual changes in \%: } \\
\hline Gross Domestic Produkt & $-1,7$ & $-1,8$ & $-4,7$ & $-8,9$ & $-5,5$ & 2,8 & 5,3 & 4,1 & 3,5 & 4,6 & 3.9 \\
\hline Employment & $-0,4$ & $-1,0$ & $-3,9$ & $-5,1$ & $-4,1$ & $-1,8$ & 0,3 & 0,8 & $-0,9$ & 0,0 & 0,1 \\
\hline Labor productivity 1) & $-1,3$ & $-0,8$ & $-0,8$ & $-4,0$ & $-1,5$ & 4,7 & 5,0 & 3,3 & 4,4 & 4,6 & 3,8 \\
\hline $\begin{array}{l}\text { Labor productivity in processing } \\
\text { activities 2) }\end{array}$ & & & & $-4,6$ & $-7,4$ & 5,0 & 12,6 & 4,2 & 7,3 & 9,4 & 7,1 \\
\hline \multicolumn{12}{|c|}{ Structure of the added value (in \%) } \\
\hline - Agriculture & 4,5 & 4,9 & 5,6 & 5,8 & 5,9 & 5,2 & 4,6 & 4,6 & 4,5 & 4,3 & 4,5 \\
\hline - Industry $(\mathrm{C}+\mathrm{D}+\mathrm{E})$ & 46,6 & 43,5 & 37,6 & 40,8 & 36,6 & 34,1 & 35,4 & 33,4 & 32,8 & 32,5 & 32,0 \\
\hline - Services & 45,2 & 49,0 & 53,7 & 51,4 & 55,0 & 58,0 & 57,3 & 59,2 & 59,5 & 59,8 & 60,3 \\
\hline
\end{tabular}

Source: Statistical Office of the Republic of Slovenia, The Statistics of National Accounts; 1998, Appraisal of the Institute of the Republic of Slovenia for Macroeconomic Analyses and Development

1) measured by a ratio between the real GDP growth rate and the employment growth rate

2) measured by a ratio between the real added value growth rate and employment growth rate in processing activities

Labor productivity in Slovenia increased in the period from 1993 to 1998 mostly as a result of a reduced employment (Table 2). It was important to stop a decrease of employment for what investment in technological and human resources development had to be ensured.

Chart 1: Indicators Of GDP, Employment And Labor Productivity In Slovenia, 1988 -1998 (Annual Changes In \%)

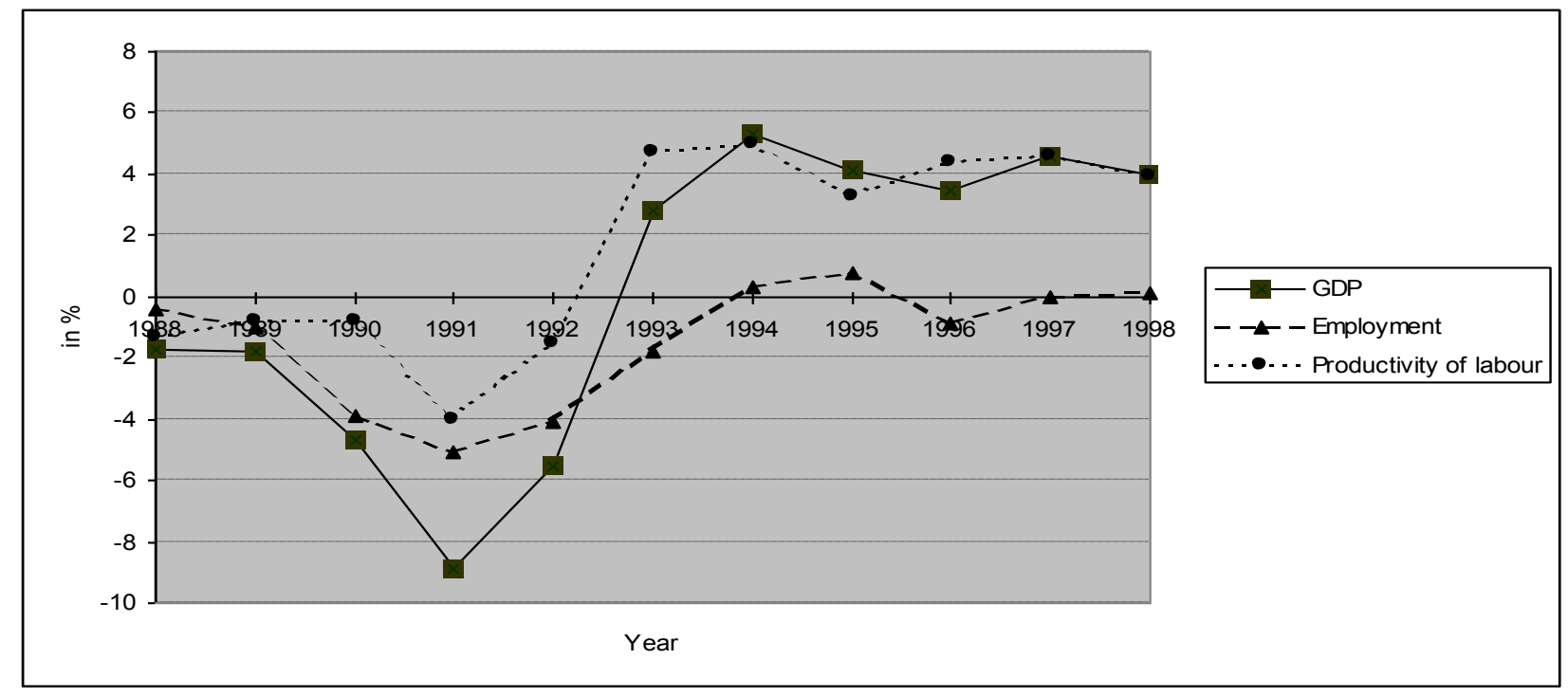

Source: Table 2

Transformation depression was accompanied with decline in economic activity in general and inflation, which both had negative impact on employment. Labor market conditions have radically changed. Many enterprises faced inevitable failure, many workers were dismissed, and it was not easy any more to find a job. The registered unemployment rate was rising up to $14.4 \%$ in 1993. The most critical groups were those having no vocational education, older than 40 (the share of those over 40 increased from $17 \%$ in 1987 to $46 \%$ in 1998) and those already 
being unemployed. The significant change was observed in structural proportions of economic sectors and in changing composition of the work force. Transformation depression has increased the demands for educated employees; those without having qualifications mostly lost their jobs. The problem was moderated with new retirement legislation, which enabled the possibility of early retirement. In time period between 1988 and 1992, the number of work force decreased for 150,000 people as the consequence of retirements. The percentage of retired among whole population was $16.7 \%$ in 1987, and has increased up to $22.2 \%$ by the year 1992 (Pirher et al., 2000, p. 15). In 1992, two active people came per one retired. Consequently, taxations increased and competitiveness of firms decreased. In 1993 the trend of retirement turned down, because the legislation has changed, the retirement age went up to 58 years for women and to 63 years for men. In spite of many negative consequences of to-early retirements, it was estimated, that if people who had been early retired joined to those being unemployed, the percentage of registered unemployment would be for $36 \%$ higher in the middle of 1991 (40\% in 1992), than it actually was (Mencinger, 1997, p. 160).

Creating market oriented economic society has forced the giant, socially owned enterprises to transform in striving to reduce their costs, and thus entering on developed, more demanding markets of Western Europe. Many small and medium enterprises arose from big socialist companies, which contributed to more harmonized structure, considering the size of enterprises. At the same time, enterprises were privatized and were organizationally and technologically modernized. Transformation depression reached the lowest point in the middle of 1993, when economic activity in Slovenia began to increase. Despite the positive economic growth, which started in 1993, and was in the period $1993-1998$ in yearly average around $4 \%$, the average registered unemployment rate remained at a relatively high level (in 1998 was $14.5 \%$ ), mostly because of large level of "hidden unemployment" before transition period. The main reasons for employment stagnation and the persistent high registered unemployment rate could be found in economy's restructure initiated by a transition into market economy (bankruptcies) and the loss of Yugoslav markets (orientation on a more demanding European markets). The long lasting privatization of common ownership has geared the restructure of enterprises, decreased the interest for investments and alleviated the links with foreign strategic partners (modest direct foreign investments), which could increase employment. Changes in the labor force demand structure have been caused by huge structural labor market discrepancies, which have led to the increased long-term unemployment (Pirher in Pirher et al., 1994; Klužer et al., 1999).

\section{LABOR RELATIONS IN POST-TRANSITION PERIOD AND RECENT TRENDS ON THE SLOVENE LABOR MARKET}

At the beginning of the nineties Slovenia found itself not just in a phase of political and economic/systemic transition, but also in a type of demographic transition. The population growth stopped. Since the early eighties the birth rate has not been high enough to maintain the population, and it is still falling. The two basic reasons are the lack of accommodation and problems in the employment of women who are expected to have children in the future. Given the declining death rate, particularly among older people, which is still falling, the proportion of the population classed as elderly is growing. Even though, it is estimated, that the size of the influx of people into the active population will be greater that the outflow for some years. The forecast of the labor supply growth in the coming years means that it will not be possible to reduce the present high rate of unemployment unless the number of people being employed grows faster than the active population. This will only happen if economic growth exceeds 4 or 5 per cent. Therefore, factors - contributing to sustainable and rapid growth in a longer period of time should be provided (Kolodko, 2004).

Despite the positive economic growth in Slovenia, which started in 1993, the registered unemployment remained at a relatively high level. The average registered unemployment rate in 1998 was $14.5 \%$ (Chart 2: columns), while the survey unemployment rate (Chart 2: line) reached $7.9 \%$ (the average registered rate was $10.6 \%$ and ILO rate was $6.3 \%$ in the year 2004). The reasons for such a big difference between both rates of unemployment occur mostly because of 1) a relatively huge contractual works, non-paid work of assisting family members, moonlighting and gray economy; 2) unemployment insurance system - enabling many benefits to unemployed people, thus rising the motive between potential unemployed to register at the Employment Service of Slovenia as being unemployed; 3) evidencing the participants of public works and on - the job training as still unemployed persons up to the end of 1998; 4) a high share of long-term unemployed persons (becoming passive in searching for a job), elderly persons and those without 
vocational education, who are passively waiting to fulfill conditions for retirement (Kajzer, 2001).

Chart 2: Average Registered Unemployment Rate And The Survey Unemployment Rate (\%)

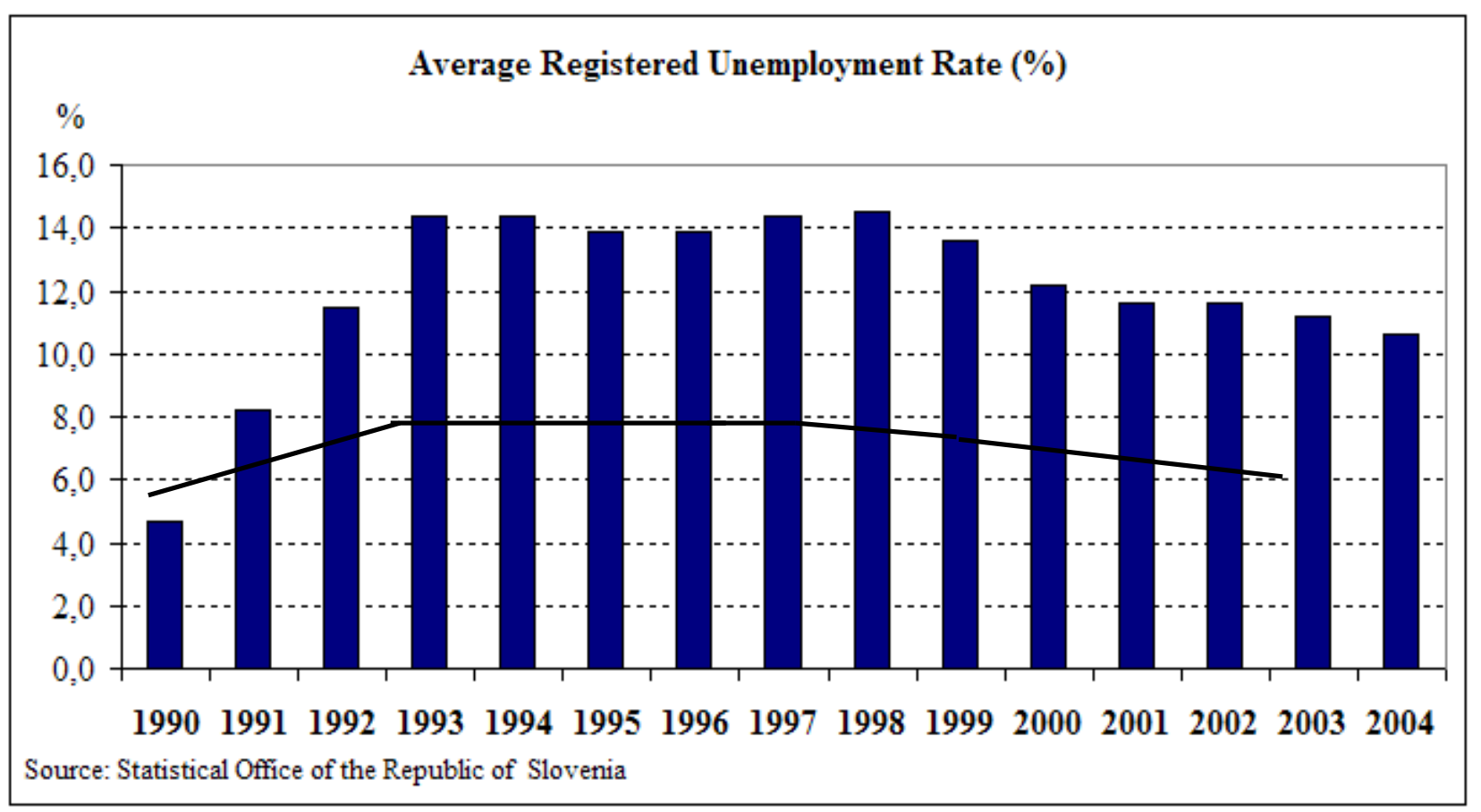

With the number of workers losing their job falling, and the number of the unemployed finding a job climbing, the recent trends of registered unemployment are much more favorable than they had been over the previous few years. The share of older and long-term unemployed people fell due to the measures of active employment policy targeted at people with low employment prospects. The differences in unemployment among regions were narrowing as well. The registered unemployment rate for 2005 was $10.1 \%$ and survey unemployment $6.1 \%$. A falling trend is also expected in 2006, with registered unemployment anticipated to drop to $9.6 \%$ and survey unemployment to $5.9 \%$.

In the year 2000, $93.0 \%$ of persons in employment were full-time employed, and only $6.1 \%$ of them part-time (Results of Surveys, 2005), which indicates quite rigid labor market in Slovenia. Part of the reason that the unemployment rate remains relatively high is linked to the process of making employment more flexible and to the tendency of employers taking on new employees to reduce the risk of costs linked to redundancies. Since the average length of fixed-term employment is becoming relatively shorter (in $199872 \%$ of all job vacancies were for temporary employment), increasing numbers of people are moving between employment and unemployment.

Technology development, necessary for Slovenian for not lagging behind the EU average, is not possible without investment in human resources development. Investments in human resources development produce no effects in a short period, but neglecting this component on the long run will, with no doubt, cause crises in economic and social development. Ageing of population, the problem Europe is and will face, is characteristic for Slovenia too. This problem does not generate only the problem of financing the existing system of social security, but it also emphasizes the need for life-long learning, while on the other hand it requires the improvement of educational system flexibility. Within the internal EU market the labor market flexibility will, along the uniformed monetary policy, become even more important factor of economy's competitiveness and adaptation capability (Klužer et al., 1999). On the other hand, it is not realistic to develop the uniformed mixture of actions, which would provide the equal level of labor market flexibility in different countries. Each country should find its own combination of factors - respecting flexibility on the one side, and security 
on the other - finding the proper ratio between both components - flexicurity (Kajzer, 2004). The employment policy is facing the dilemma whether to support or to limit flexible patterns of work and employment. In this first case it would contribute to the flexibility of employers and to the decreasing social security of employees. In the second case it would decrease the possibility of employers to quickly adjust to the market changes but it would preserve higher social security of the employees. Perhaps a partial regulation of flexible patterns of work and employment is needed (Svetlik, 1994). The role of social partners is getting more and more important in searching for "secure flexibility" (Kajzer, 2005).

The success analyses of recent employment policy programs show, that it is still necessary in the future to direct measures toward the further increase of labor market flexibility, promotion of creating new jobs and alleviation of measures to preserve the existing jobs. Although data on unemployment point at the problem of labor market structural discrepancies, the problem is also in a very modest demand. The population's low activity rate, which causes problems in financing the existing system of pension and disability insurance, is not only the consequence of demographic trends but also of programs on early retirement, introduced in the early 90 s. These programs have reduced the potential registered unemployment by encouraging the exit of employed persons from labor force to non-active population. Recent trends are completely reverse, as pre-retirement schemes are being replaced with the postponement of pension age - encouraging flexible employment (retirement).

\section{BASIC LABOR MARKET INDICATORS: COMPARISON OF SLOVENE AND EU}

It would be absurdly to compare labor market situation in Slovenia with USA, as it will take the EU until 2023 to reach US levels of employment, and then only if EU employment growth will exceed that of the US by $0.5 \%$ p.a. (Sicherl, 2005), so we have compared and tried to place Slovenia somewhere within European space.

When comparing the labor market indicators between Slovenia and EU countries, it became clear, that each country had its own approach to more or less similar problems, depended on cultural background and socio-economic factors. Adopting a special statistical method - a cluster analysis enabled to group EU countries in accordance with some similarity, based on 55 variables from the Labor Force Survey. Those variables indicated that in the European area we could detect at least four distinctive types-models of labor market: flexible type (Denmark, Great Britain and The Nederland), continental type (Belgium, Germany, Austria, Luxembourg, France, Sweden and Finland), traditional "industrial" type (Ireland, Portugal, Slovenia) and Mediterranean type (Greece, Italy and Spain). Based only on the flexibility-indicators, three even more distinctive models of labor markets in the (western) European area appeared. These are: modern, flexible labor market (Denmark, Sweden, Finland, Great Britain and the Nederland) with grater share of part-time and temporary employment; balanced labor market (Belgium, Austria, Germany, France and Luxemburg); and traditional labor market (Greece, Ireland, Italy, Spain, Portugal and Slovenia) with higher shares of persons in employment in agriculture and industry and grater emphasis on the self-employment (Ignjatović, 2002).

The international comparison of Slovene and EU basic labor market and sector-employment structure indicators shows a similarity of problems and indicates possibilities for further development and increase of employment in service sector. The EU rate of unemployment was, in 2004, approximately $8.9 \%$ and was higher than in Slovenia where it was 6.3\% (5.8\% in December 2004). Comparing with other EU countries, the survey unemployment rate is not high. Other countries obviously have higher survey unemployment rates (EU-15 average was $8.1 \%$ and EU-25 - 9.1\%). Lower survey unemployment rates than Slovenia is characteristic for Austria and Ireland.

The comparison between registered unemployment (10.6\%) in Slovenia and ILO unemployment shows, that the registered unemployment rate is still much higher than the ILO unemployment rate, as $44.0 \%$ of registered unemployed persons in Slovenia were not ILO unemployed - among them 14.6\% performed at least one hour of work for payment or family gain in the week before the survey and 5.8\% could not accept work in two weeks after the survey (Rapid Reports, 2005). 
A comparison of the structure of persons in employment shows a high share of assisting family members and various kinds of un-formal types of work, which reduce social costs of transition and, to a certain extent, improve the labor market situation.

It should be taken into account, that Slovenia's productivity is the highest among the new EU members and already exceeds that of Greece, but is still half the average of the 15 older EU member states. In Slovenia labor costs (taxes and social contributions paid by employees and employers) are the highest in the new EU member states with the exception of Cyprus. If Slovenia wants to boost employment and economic growth, the European Central Bank (ECB) and the European Commission warn, it will have to create a more flexible labor market (Rednak in Slovenian Business Report, 2004).

According to some labor market flexibility measures Slovenia still lags behind EU although the increased labor market flexibility has been evidenced. In 2004 the share of persons in employment - working part time was 9.3\% (Rapid reports, 2005). Considering part-time employment, the leading country is Nederland with $45 \%$, which is followed by the group having the percentage between 16 and 24 (Belgium, Denmark, France, Germany, Ireland, Austria, Sweden, and Great Britain). Slovenia can be sorted in the group (Hungary, Malta, Lithuania, Cyprus, Greece, Spain etc.), having less than $10 \%$ of working-population, being part-time employed (Kajzer, 2005a). Very modest share of part-time employed people in Slovenia is also a consequence of extremely low share of elder people employed, due to early retirements in the beginning of 90 's. In year-group 55-64, there was only $23.5 \%$ people employed in the year 2004 (Kajzer, 2004a), which is much faraway from Lisbon strategy - planning the 50\% employment by the year 2010 in the same age-class, and even far from EU-15 average, which is $41.7 \%$ and EU-25 with $40.2 \%$. In Denmark, Estonia, Portugal, Finland, Sweden and the United Kingdom, the rate in the year 2004 was higher than 50\%. In France, Latvia, Hungary, the Netherlands and Finland, the rates increased by at least 7 percentage points compared to 2000. Four countries remained below 30\%: Poland (-2.2 p. p.), Austria (unchanged), Slovakia (+ 5.5 p. p.) and Slovenia, where the employment rate of older people increased by 6.3 p. p. in 2004, compared to 2000 (Jouhette, Romans, 2005).

Chart 3: Employment Rates Of Persons Aged 55-64, EU-25, 2000 - 2004

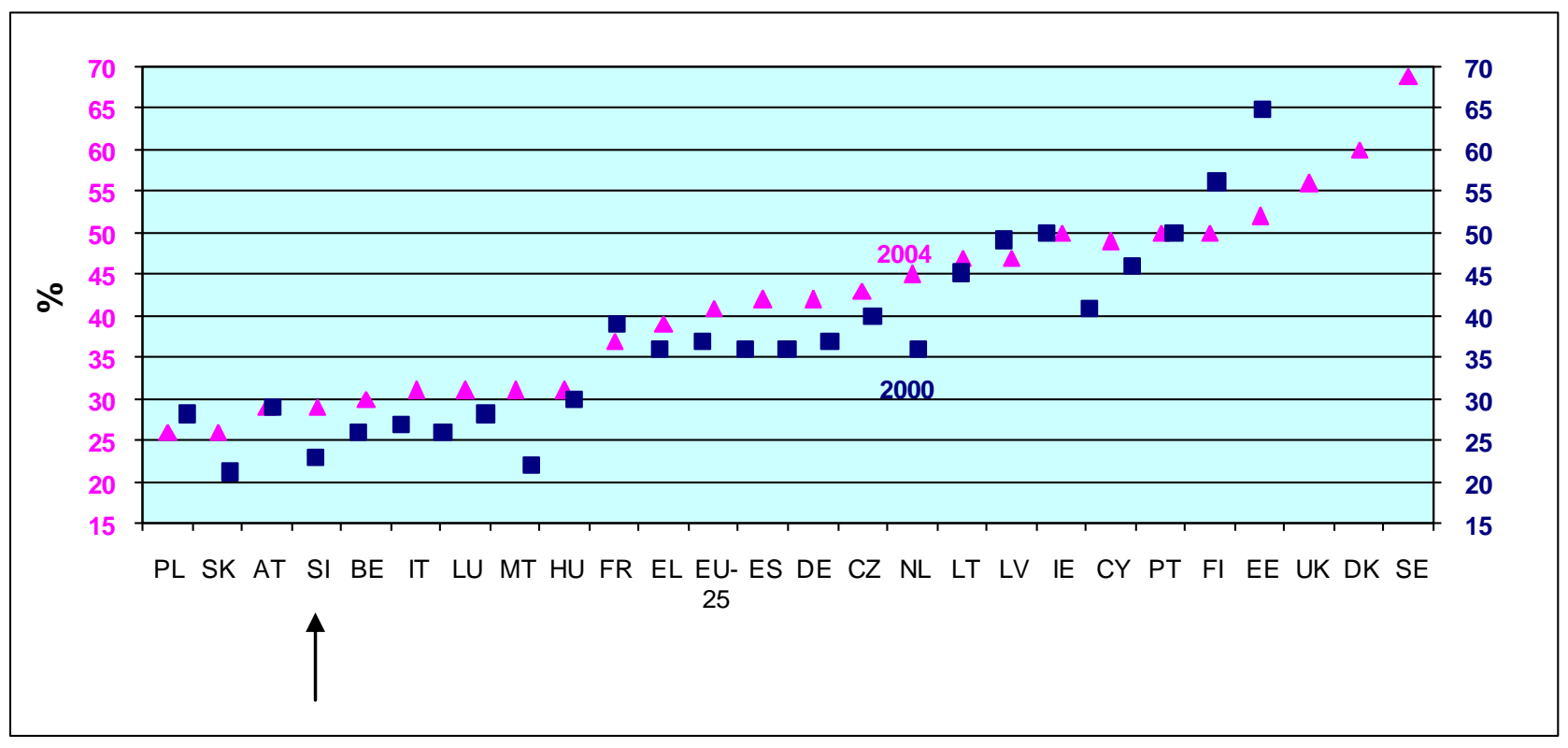

Source: Eurostat, European Union Labour Force Survey (LFS) in Jouhette, Romans, 2005. 
Slovenia largely lags behind according to the share of women employed part-time. The share of women employed part - time in the year 2003 (Lopez et al. in Eurostat Yearbook 2004) was the highest in Netherlands with $74 \%$, Norway $-46 \%$, United Kingdom - 43\%, Germany - 40\%, Belgium - 39\%, Sweden and Austria - 35\%, Denmark - 32\% ...etc., while in Slovenia it was 9\% in 2003 and 10,9\% in 2004 (Rapid Reports, 2005).

The population's activity rate in EU-15 was 64.3\% (and 62.9\% in EU-25) in 2003 (Lopez et al. in Eurostat Yearbook 2004), what is comparing with Slovenia (the employment rate was between $62 \%$ and $63 \%$ in last ten years) almost equal, while differences appear among individual countries (e.g. EU-10, new member states have the average $55.9 \%$ ). Countries with the highest share are Denmark (75\%), the Netherlands (73\%), Sweden (72\%), and United Kingdom (71\%). Slovenia has quite high activity rates mostly due to high labor force activity rate of women (57\%), which is higher than EU-15 average.

Another field where Slovenia needs to improve its position is educational structure. Slovenia is facing the problem of unfavorable education of its population. According to the last count of the population, in 2002, there were around $34 \%$ persons (Table 5), aged over 15, having finished a primary school or less, more than a half of them were older than 50 (Rapid reports, 2005). The school expectancy - the expected years of education over a lifetime in Slovenia is 17.4 in the year 2003 (Andren, Schmidt in Eurostat, 2005), which has caught up the EU average (17 years), but at the beginning of the $90 \mathrm{~s}$, the average duration of education of adults - older than 25 , was only 9.6 years. The achieved education is one of the key indicators of defining the labor market situation; moreover, educated, trained and knowledgeable population is the best guarantee for wealth of any nation.

The comparison of population's or labor force educational structure in different countries shows, that Slovenia is still lagging behind developed countries at secondary as well as at higher and university level. The share of persons with higher or university education in the entire population was for example, in 2002, in Slovenia 13\%, France 23\%, Germany 21\%, the Netherlands 25\%, Sweden 28\% and in Great Britain 23\%. (Statistical Office of the Republic of Slovenia 2004; Klužer et al., 1999). When analyzing the educational structure of those - being unemployed, the results were even worse; in the year 2004, there was 3\% (and 4.9\% in the year 2000) of unemployed persons without having school education or with incomplete elementary school, $22.2 \%$ - having elementary school, $33.9 \%$ - with lower or middle vocational education, $26.3 \%$ - upper secondary professional education, 5.3\% - general upper secondary education, $3.5 \%$ having post-secondary vocational education and $5.6 \%$ - with higher and postgraduate level of education (Results of surveys No 811/2005, p. 89; Rapid reports, 2005).

Education is not only the staring point in improving employability in general, but it is significantly in correlation with entrepreneurial activity, which is without doubt one of the most important factor in new job creation and simultaneously developing self-employment intentions. It is however, related to the type of economic activity and expected firm's growth (GEM, 2001, p.17; Erikson, 2001); the percentage of entrepreneurs anticipating substantial growth was significantly higher (31 percent) in those with graduate experience. People with higher education are more open to team work and tend to join their capital or firm with partners, thus enabling the firm's growth. Educated entrepreneurs are more self-confident and are not afraid of failure. Lack of necessary skills and knowledge usually results in the fact, that Slovene enterprises mostly remain micro firms (very often based on self-employment). In striving to become a learning society, Slovenia should concentrate on developing high-tech, knowledge-based, fastgrowing enterprises, led by highly educated, ambitious entrepreneurs. Therefore it is important to utilize educational dimension as the prosperity of high-tech and fast growing enterprises can be achieved primarily by educating potential young entrepreneurs (Dimovski, Žnidaršič, Penger, 2005). 
Table 5: Population Aged 15 Years Or Over By Activity Status, Educational Attainment And Sex, Slovenia, Census 2002

\begin{tabular}{|l|c|c|c|c|c|c|}
\hline & $\begin{array}{l}\text { Total population } \\
\text { aged 15 years or over }\end{array}$ & \multicolumn{4}{|c|}{ Labor force } & $\begin{array}{c}\text { Inactive } \\
\text { population }\end{array}$ \\
\cline { 2 - 7 } & & Total & \multicolumn{2}{c|}{$\begin{array}{c}\text { Persons in } \\
\text { employment }\end{array}$} & $\begin{array}{c}\text { Unemployed } \\
\text { persons }\end{array}$ & $\mathbf{1 3 0 4}$ \\
\hline Total & $\mathbf{1 6 6 3 8 6 9}$ & $\mathbf{9 4 9 0 7 8}$ & $\mathbf{1 0 0 \%}$ & $\mathbf{8 1 8 3 0 4}$ & $\mathbf{1 3 0 7 7 4}$ & $\mathbf{7 1 4 7 9 1}$ \\
\hline No education & 11337 & 2225 & 0.14 & 1132 & 1093 & 9112 \\
\hline Incomplete basic & 104219 & 24867 & 1.94 & 15869 & 8998 & 79352 \\
\hline 1-3 grades of basic school & 11181 & 1525 & & 653 & 872 & 9656 \\
\hline 4-7 grades of basic school & 83863 & 20261 & & 12997 & 7264 & 63602 \\
\hline $\begin{array}{l}\text { incomplete basic school and } \\
\text { vocational training programs }\end{array}$ & 9175 & 3081 & & 2219 & 862 & 6094 \\
\hline Basic & 433910 & 155984 & 14.73 & 120506 & 35478 & 277926 \\
\hline Upper secondary & 899341 & 596795 & 63.42 & 518982 & 77813 & 302546 \\
\hline Lower vocational & 70544 & 39437 & & 31523 & 7914 & 31107 \\
\hline middle vocational & 381748 & 275374 & & 237198 & 38176 & 106374 \\
\hline technical and professional & 337665 & 233329 & & 208675 & 24654 & 104336 \\
\hline general & 109384 & 48655 & & 41586 & 7069 & 60729 \\
\hline Short-term tertiary & 84044 & 60909 & 7.07 & 57824 & 3085 & 23135 \\
\hline $\begin{array}{l}\text { Higher undergraduate and } \\
\text { postgraduate }\end{array}$ & 131018 & 108298 & 12.71 & 103991 & 4307 & 22720 \\
\hline
\end{tabular}

Source: Statistical Office of the Republic of Slovenia, 2004

The participation of population in formal education in Slovenia is relatively high up to the age of 18 , while after that it decreases. The participation of young persons in the year $2002-2003$ was about $86 \%$ (Andren, Schmidt, 2005). Consequences of a relatively huge dropout of young persons from secondary schools are reflected on the labor market as well as in educational system itself. On the one hand, the dropouts increase the range of poorly educated labor force and on the other; they fulfill placements in adult educational programs. Recent trend shows, that younger generations stay in education longer and exit the education system better qualified than previous generations. The educational achievement of youth has thus significantly improved. The share of tertiary students in Slovenia is comparable to the EU-15 countries, while the share of graduates in Slovenia aged over 30 is below the shares in old Member States. Participation of adults in education and training as well as investment by employers in human capital development are still relatively low.

The changes in economy, in the 90s, caused crucial changes in employment structure by sectors. The share of persons employed in service sector increased in 1987 from 40\% to 52.9\% in 2004 (Rapid reports, 2005). The largest increase was evidenced in the area of financial services. Other services increased by a smaller range like traffic, warehousing and communications, real-estate business, education, health service and social security, other public, joint and personal services.

Despite the service sector strengthening in the last few years, Slovenia is still lagging behind developed countries according to the share of labor force employed in the service sector. In some developed countries this share exceeds $70 \%$, even Greece and Spain (as the two less-developed countries) have higher share (55\%) than Slovenia (52.9\%). Growth of employment in the next few years will, in a large extent, depend on development of service sector or the increased number of new jobs. But a development of services is strongly related with a development and modernization of the Slovene processing sectors.

Circumstances on the labor market, in major part, reflect the situation in the economy, while the growth of employment is closely related with the economic growth. Economic trends in Europe, especially in the last two decades, have shown that the economic growth is a needed but not a sufficient condition for the growth of employment. Factors, determining labor market flexibility, are becoming important for the growth of employment. The newest Slovenian employment protection and labor legislation in general is comparatively liberal, except for disabled persons, who cannot be dismissed until a new job is assured for them. The new Law on Labor Relations 
includes the requirements of EU Directives applying to labor law.

\section{NEW LAW ON LABOR RELATIONS IN SLOVENIA: THE LABOR RELATIONS ACT}

Since 2000, which saw a decline in the number of registered vacancies, demand began to grow in 2003 . The relationship between fixed-term and permanent employment has changed in the last decade. As employers prefer to offer work on a fixed-term basis, about $70 \%$ of the reported vacancies are for temporary employment. Temporary work thus continues to be the predominant form of employment offered by employers that report demand for labor. A continuation of this pattern should lead to a gradual fall in the number of people in permanent employment, who still currently form the majority of persons in employment. In 2004, the strongest growth in employment was recorded in some public and business services and in construction, while industry and transport have seen an ongoing decline. Economic levers were forcing the majority of employers to implement new forms of labor relations, with emphasize on labor cost reduction, which could only be achieved by reducing labor law restrictions and by implementing the new labor legislation.

The recent labor-law regulation of labor relations brought the significant changes in regulating labor relations concerning their new contract-based character, as the previous law on labor relations was still based on the associative regulation (the mutual regulation of labor relations). Although before the new Law on labor relations came into force on January 2003, the collective agreements were introducing the market-economy elements on the labor relation's field, the new Law on labor relations enabled the full involvement of market-oriented labor relations. The main function of this act is to protect the employee as the weaker party in labor relation, but at the same time to enable employer to successfully perform their enterprises and the business process.

The new employment act is of significant importance, providing for the first time in a decade, an integral set of regulations governing relations between employers and employees. With the newly adopted Labour Relations Act, an important step forward has been made in terms of flexibility of the labor market. The Act sets the legal framework for all kinds of flexible forms of employment, determines special arrangements for small enterprises, and enables working hours' flexibility according to EU standards. It also ensures equal treatment of women and men in employment, training, vocational training, pay, working conditions and other employment related issues. A result of multi-year negotiations between social partners - the government, employers and trade unions - the document is aligned with EU standards and the recommendations of the International Labour Organization (ILO). It introduces a number of new plans, most notably the qualification of employment as a contractual relation. As a result, employment is an arrangement between two parties, yet since the employee is the weaker party, they get special protection by law.

The basis of the employment relation is the employment contract, where mutual obligations of both sides are set down. The contract itself is nothing new; what is new about it is that it must lay down precisely what kind of work the employee will do, the wage, the working hours, annual leave and other rights. Since it delineates the rights and obligations of both sides, it can only be changed with the consent of both parties.

No major changes have been made to the scope of employee rights, but the new act has assumed some rights that had previously only been dealt with in collective agreements and thus broadens the extent of minimal legally determined rights. The new rights which all employers must provide include bonuses for nightshifts, overtime work and work on holidays and Sundays; age benefits; special bonuses for annual leave; severance pay upon retirement; and the reimbursement of commuting and lunch expenses. The act only supplies employees with the bare minimum of rights; they can be set higher with collective or individual employment agreements.

One of the ways in which the employment contract can be terminated is the notice of leave. The old legislation only gave the employee the right to terminate employment this way, but the new act also gives the employer the right to do that. Since the employee is considered the weaker party, the employers are limited in their capacity to dismiss workers. While the employee can terminate employment without giving grounds for the decision, the employer can only terminate it based on serious and provable reasons. According to law, employees can quit their job due to business reasons, while employers must prove the worker's incompetence or malpractice. The act does stipulate when the grounds for dismissal are unjustified, but it does not say when they are serious and justified. The real legal framework will only be 
established through practice, when labor courts decide on disputes regarding dismissals.

Some categories of workers enjoy special protection from dismissal - notably representatives of employees (members of workers' councils and representatives of trade unions), parents (women while they are pregnant or breastfeeding a child and parents on maternity leave), disabled people and employees who are absent due to illness, as well as older workers, up until the time when they meet the minimum criteria for retirement.

The new Labor Relations Act does not influence (or change) the collective agreements and employment contracts that had been already set.

\section{KEY LABOR MARKET DEVELOPMENT PROBLEMS IN SLOVENIA AND KEY ORIENTATIONS AND POLICIES - ALLEVIATING THEM}

The situation on the labor market usually reflects the situation in the economy, demographic fluctuations and social development, which all are inter-related. The following factors influence on labor market: technological and development lagging behind of industry, development lagging behind of service sector, lagging behind in production and provision of quality products, insufficient profitability of products and enterprises, poorly trained employed persons and managers to act in a global economy, not finished privatization and the lack of favorable investment opportunities. In brief, it can be said that the following factors and problems condition the situation on the labor market in Slovenia:

- $\quad$ Educational, vocational and regional discrepancies,

- Huge number of unemployed people in "risk groups" such as those aged over 45, persons with the reduced employability due to medical or other reasons, disabled persons, etc. Their share represents nearly a half of all unemployed persons,

- $\quad$ To big inflow of unskilled labor force from the education system as a consequence of a high rate of drop-out in the system of vocational school,

- $\quad$ High share of moonlighting,

- The lack of suitable institutions which could, to a certain extent, guarantee modern approaches to train and retrain labor force,

- Insufficient participation of adults in educational and training programs,

- $\quad$ Obstacles for establishment and development of SMEs.

Although until recently Slovenia did not have a typical market system but only some of its elements, it started to develop active employment policy instruments in the eighties. Slovenia has developed the system of public employment services, which could, in respect of their activities, be easily compared with similar services in market economies.

As a consequence of the economy's great structural changes (which led to labor market structural changes) and the lack of labor demand, new programs were created at the beginning of the nineties: co-financing the cost of creating new jobs, promotion of entrepreneurship and self-employment, promoting employment of disabled persons, and investments in human resource development. Owing to the sharp economic recession as a consequence of lost markets, a program of preserving productive workplaces has also been introduced (co-financing the cost of solving the problem of redundant workers). The programs also promoted the workforce alleviation from the labor market (purchase of additional years of work - until 1993), and performed a number of educational and training programs.

Along with the newly created programs, the size and the content of the existing introduced programs have also changed (subsidizing the labor force in companies employing disabled persons; programs of awareness raising and assistance offered to unemployed people for planning their professional career; psychosocial rehabilitation programs for long-term unemployed persons; etc.). 
The key orientations (following EU employment policy) - alleviating critical elements of labor market development in Slovenia are (Glas, 2003; Klužer et al., 1999; Kajzer, 2005):

- Developing competitive economy increasing the economy's flexibility and competitiveness; growth of employment can only be ensured by stable economic growth, based on a stepped-up technological modernization of industry, greater investment in know-how and innovation, creation of a favorable environment for investments (Slovene and foreign direct investment), promotion of small and medium-sized enterprises (formation of small business networks and developing entrepreneurial culture to improve conditions for the creation of new jobs in enterprises), development of service activities and the renewal of businesses in rural area,

- $\quad$ Forming more efficient and cheaper state-administration; restructuring of national funds...

- $\quad$ Developing a contemporary welfare state - actively solving the problems of unemployment; the priority objectives in implementing the employment policy are, as follows (Klužer et al., 1999): to constantly monitor the impact of tax levies and incentives on employment, to reduce the range of moonlighting, to reduce frictional unemployment and structural discrepancies, by reducing the share of long-term unemployed persons (to 40\%) and unemployed persons without basic vocational education (to 25\%), to ensure participation of all unemployed persons, in active employment policy programs, to increase employment, which in average should exceed $1 \%$ annually, taking into account a fast growth enabling the reduction of unemployment rate to approximately $6 \%$, by using the international methodology or registered unemployment to around $9 \%$, to develop more flexible labor market and efficient system of social insurance, to decrease social exclusions...etc.,

- $\quad$ Rising the efficiency in gaining, transferring and applying of knowledge for economic development enabling the formation of quality jobs - in connection with human resource development; the strategic goals in this segment are: to reduce labor market structural discrepancies, to ensure equal labor market access, to raise educational level (of labor force) and to reduce the dropout rate, to improve the position of young people on the labor market, and to develop the culture of life-long learning.

The key bodies in charge of increasing the employability of the population are the Ministry of Labor, Family and Social Affairs and the Ministry of Education and Sport, and the key bodies carrying out the related assignments are the Employment Service of Slovenia ${ }^{1}$, the Vocational Training Centre and the Adult Education Centre of the Republic of Slovenia. The Ministry of Labor, Family and Social Affairs has developed two basic documents: Strategic goals of labor market development by the year 2006 and Action employment policy program - based on European model (Amsterdam contract). The Employment service of Slovenia is individually oriented and it is working on many programs in context of active employment policy: continuous education and training, encouraging self-employment, public works, regional and local employment programs, restructuring of enterprises.

The strategy can only be successfully implemented if permanent and on-going co-operation by various governmental economy sectors, branches responsible for labor, education, finance and social partners' institutions on the harmonization of polices and their objectives within an individual business period for the enactment of employment strategy is guaranteed. The present active employment policy system is not sufficiently created on the active role of social partners and it is still financed predominantly from the national budget. Development of social partnership is important at all levels - national, local and entrepreneurial.

\footnotetext{
1 The Employment Service of Slovenia guarantees the users of its services a professional assistance in entering the labor market and thus it contributes to increased employability, decreased unemployment and better social security. The basic objectives of the Employment Service of Slovenia are: to shorten the registration period of unemployed people at the ESS, using an efficient approach; to achieve comparability with the EU employment services with the quality development of services; to proactively cooperate with the ESS' partners in order to achieve the key targets of labor market development; to release funds for the word with difficult-to-employ people with the development of contemporary forms of work; to guarantee the ESS' users their material rights timely and adequately.
} 
The state is also setting up the appropriate institutional framework - increasing the number of people participating in public works programs and programs for the creation of new jobs for the long-term unemployed persons (difficult-to-employ groups of unemployed in particular). The new Law on Labor Relations, has simplified procedures of hiring and discharging (especially for small employers) and thus increased the labor relation flexibility. The Law on Changes of the Law on Employment and Unemployment Insurance (Official Gazette of the RS, No. 69/98), brought a number of changes - one of these is that active employment measures prioritize active and less passive measures. The changes are, in particular, focused on removing deficiencies and weaknesses of unemployment insurance system to which Slovene and foreign experts have been drawing attention for years (the World Bank, OECD, and Phare). The Law on Changes specifies in detail, the conditions under which a person may acquire the status of an unemployed person. It also stimulates unemployed people to be more active when searching new employment and to integrate themselves in new employment.

Promotion of human resources development has, up to now, been a subject of active employment policy. Ministry of Labor, Family and Social Affairs has oriented active employment policy among others also to investments in human resources development, training programs for unemployed persons and retraining programs, which are implemented also in the co-operation with the Ministry of Small Business and Tourism and The Ministry of Science and Technology, which stimulates young researchers and co-finances the costs of research-development activities.

Modern social system should undergo profound changes in the system of social security to adapt it to the new conditions. Ignjatović (2002) suggests: the concept of full employment should be reduced from "full-time employment for all" to "any kind of employment for all"; the concept of security, in which the status of flexible employment should be normalized - equalized to standard forms of employment; forms of family and individual friendly arrangements (flexicurity); and employability as proactive measure and ability to cope with the flexibility and the future.

Nevertheless employees - being used to high level of protection at work, having many rights in past, including guaranteed full-time jobs of unlimited duration, are slowly adapting to new labor relations, employers see the development and growth possibilities in flexible forms of work and rewarding. The positive consequence of flexible labor market can already be seen in more possibilities for employment and in unemployment period - which is shortening. Anyway, the regulation of labor relations needs to be negotiated - involving all social partners before setting the necessary legislation, as the field of labor relations is very subtle, having a great influence on economic and social sustainable development in future.

\section{CONCLUSION}

In Slovenia, which is becoming more and more open economy, the influence of external markets and the consequences of economic restructuring in the transition period have led also to labor market changes, which forced the implementation of new dimensions of labor relations. The restructuring of the economy is still not complete. The relative importance of different sectors of the economy is still changing, with agriculture declining rapidly and industry somewhat more slowly, while the service sector is expanding. The international competitive environment and modern flows of economic development require a different, essentially more dynamic and flexible work place, with a different structure of knowledge; for this reason, higher levels of professional training, increased labor relations flexibility and thereby a more flexible, higher quality supply in the labor market, represent the only real option for solving the labor related matters.

Just active employment policy alone (more active employment programs, including public work programs) will not be enough to ensure employment growth and a related decrease of the unemployment rate in the next few years. The objective can be fulfilled, if conditions (conducive for the creation and growth of new small and mediumsized enterprises, higher growth in business investments (Slovene and foreign direct), faster technological development and greater investments in human resources) are ensured. Such an approach to the labor related issues and employment policy can no longer be in an exclusive domain of the Ministry of Labor, Family and Social Affairs and will play a role in the formulation of all economic policy measures adopted by the Government. At the same time the responsibility for tackling the issues of labor market and labor relations is no longer in an exclusive domain of the 
Government but in a domain of all social partners, both at the national and regional levels.

Renewed Lisbon strategy has brought forward the package of integrated directives of economic policy in the time period 2005 - 2008, based on grater flexibility of labor market - which would be compatible with modern systems of social security, enabling also elder people to stay active and finally based on enlargement in quantity and improvement in quality of investments in human resources. This strategy offers a good base for Slovenian authorities when "architecting" new strategic goals - influencing labor relations.

\section{REFERENCES}

1. Andren Birgitta, Schmidt Pascal: Statistics in focus - Population and social conditions - 10/2005. Eurostat, 2005. URL: http://publications.eu.int

2. Adam Jan: Why did the Socialist System Collapse in Central and Eastern European Countries? New York: St. Martin's Press, Inc., 1996. 244 pgs.

3. Dimovski Vlado, Žnidaršič Jana, Penger Sandra. Dimensions of entrepreneurial activity : the case of Slovenia. V: EABR \& TLC Conference, Athens, June 13-17, 2005 and Santorini Island, June 20-22, 2005. Refereed proceedings. [Littleton]: Western Academic Press, 2005, 13 pgs.

4. Erikson Truls: Entrepreneurial Capital - The Emerging Venture`s Most Important Asset \& Competitive Advantage. V: Entrepreneurship research conference 2001. Babson: Babson College - Jonkoping International Business School, 2001. 8 pgs.

5. $\quad$ European Commission: Employment in Europe 2000. Brussels, 2000, 118 pgs. http://www.mszs.si/eurydice/pub/eu/empleurope2000_en.pdf

6. Glas Miroslav: Ocena pogojev za podjetništvo v Sloveniji. Osnutek za raziskavo GEM, Slovenija 2002. 12/12-2002-6/1-2003. In Slovenian.

7. Ignjatović Miroljub: Družbene posledice povečanja prožnosti trga delovne sile. Ljubljana: Fakulteta za družbene vede, 2002. 242 pgs. In Slovenian.

8. Jouhette Sylvain, Romans Fabrice: Labour market. Statistics in focus - Population and social conditions 9/2005. Eurostat, 2005. URL: http://epp.eurostat.cec.eu.int/cache/ITY_OFFPUB/KS-NK-05-009/EN/KSNK-05-009-EN.PDF

9. Kajzer Alenka: Trg dela in brezposelnost v Sloveniji. Doktorska disertacija. Maribor: Ekonomsko - poslovna fakulteta, 1996. 241 pgs. In Slovenian.

10. Kajzer Alenka: »Nova« politika zaposlovanja - prvi rezultati v Evropi in začetni koraki doma. Bilten EDP: Slovensko gospodarstvo pred novimi izzivi, marec 2001, letnik XXIV. Maribor: Univerza v Mariboru, Ekonomsko-poslovna fakulteta Maribor, Institut za ekonomsko diagnozo in prognozo, 2001, pp. 37-48. In Slovenian.

11. Kajzer Alenka: Fleksibilnost trga dela - o pojmu, dejavnikih in pomenu za zaposlenost in brezposelnost. Ljubljana: Urad Republike Slovenije za makroekonomske analize in razvoj. IB revija. Revija za strokovna in metodološka vprašanja trajnostnega razvoja. Št. 1-2 / letnik XXXVIII / 2004, pp. 108-116. In Slovenian.

12. Kajzer Alenka: Lizbonski zaposlitveni cilji nedosegljivi brez strategije aktivnega staranja. Ljubljana: Finance, sreda, 30. Junij 2004, št. 125, pp. 8-9. In Slovenian.

13. Kajzer Alenka: Slovenija mora začeti iskati varno fleksibilnost na trgu dela. Ljubljana: Finance, četrtek, 02. Junij 2005, št. 105, p. 8. In Slovenian.

14. Kajzer Alenka: Delne zaposlitve so priložnost za prožnejši trg dela. Ljubljana: Finance, petek, 12. Avgust 2005, št. 156, p. 9. In Slovenian.

15. Klužer Franci: Strateški cilji razvoja trga dela do leta 2006, politika zaposlovanja in programi za njeno uresničevanje. Pregled, Ljubljana: Ministrstvo za delo, družino in socialne zadeve, november - december 1999. In Slovenian.

16. Kolodko Grzegorz W.: Dohitevanje v državah z razvijajočim se tržnim gospodarstvom. Ljubljana: Urad Republike Slovenije za makroekonomske analize in razvoj. IB revija. Revija za strokovna in metodološka vprašanja trajnostnega razvoja. Št. 1-2 / letnik XXXVIII / 2004, pp. 142-153. In Slovenian.

17. Lopez A. et al.: Labour market - People in the labour market. Eurostat Yearbook 2004, The statistical guide to Europe, Chapter 2: People in Europe. European Commission. Luxembourg: Office for Official Publications of the European Communities, 2004. Pp. 85-90. 
18. McConnell Chambell R., Brue Stanley L.: Contemporary Labor Economics. 4th ed. New York: McGrawHill, 1995. 653 str.

19. Mencinger Jože: Spremembe na trgu delovne sile. Slovenska ekonomska revija, Ljubljana, 48 (1997), 1-2, pp. 151-165. In Slovenian.

20. Pirher Sonja et al.: Zaposlovanje: približevanje Evropi. Ljubljana: Fakulteta za družbene vede, 1994. 239 pgs. In Slovenian.

21. Pirher Sonja et al.: Background Study: Employment and labour market in Slovenia. 1st ed. Ljubljana: National VET Observatory Slovenia, 2000. 89 pgs.

22. Rapid reports. 15. July 2005, No 185. Labour market. No 16. Statistical office of the Republic of Slovenia, 2005. 34 pgs.

23. Rednak Andreja: Death, Taxes, and New EU Members. Slovenian Business Report, Winter 2004. Ljubljana: GV Skupina, GV Revije. Pp. 74-77.

24. Results of Surveys, No 811/2005. Labour market, Slovenia 2000. Ljubljana: Statistical office of the Republic of Slovenia, 2005. 292 pgs.

25. Reynolds Paul D., Camp S. Michael, Bygrave William D., Autio Erkko, Hay Michael: Global Entrepreneurship Monitor: 2001 Executive Report. London: Babson College, Kauffman Center for Entrepreneurial Leadership, London Business School, 2001. 57 pgs.

26. Rozman Vilko in Novak Janez: Sklenitev delovnega razmerja in razporejanje delavcev. ČGP Delo. Gospodarski vestnik, Ljubljana, 1981. 274 strani. In Slovenian.

27. Sicherl Pavle: Time for a fresh start - But time is not on our side. A Comparison of European and US Economies Based on Time Distances. Brussels: Eurochambres, Chamber House, March 2005. 4 pgs.

28. Statistical Office of the Republic of Slovenia 2004, Census 2002.

29. Statistični letopis Republike Slovenije 2001. Ljubljana: Statistični urad RS, 2001. (Statistical Yearbook of Slovenia, 2001). In Slovenian.

30. Strohsack Boris: Delovna razmerja, druga dopolnjena izdaja; Zveza delavskih univerz Slovenije, dopisna delavska univerza Univerzum, Ljubljana, 1981, 100 strani. In Slovenian.

31. Svetlik Ivan: Fleksibilne oblike dela in zaposlitve v Sloveniji. V: Pirher et al.: Zaposlovanje, približevanje Evropi / FDV, Zbirka Teorija in praksa, Ljubljana, 1994. In Slovenian.

32. Šnkovec Janez: Delovna razmerja, osebni dohodki in skupna poraba v združenem delu; Praksa ustavnih sodišč in sodišč združenega dela. ČGP Delo. Gospodarski vestnik, Ljubljana, 1983. 224 strani. In Slovenian.

33. Zavod Republike Slovenije za zaposlovanje, Letno poročilo, 2004 / Annual report URL: http://www.ess.gov.si/eng/Presentation/Unemployment_datoteke/frame.htm 